\title{
The Effect of Laughter Therapy on Reducing Anxiety Level in Hypertension Patients
}

\author{
Erna Purnamasari, \\ Arvina Andhiyani \\ Institute Health Sciences of \\ Strada Indonesia \\ Email: \\ ernapurnamasari@24gmail.com
}

Received: October $4^{\text {nd }} 2021$

Accepted : October $15^{\text {rd }} 2021$

Published: November $27^{\text {th }} 2021$

\begin{abstract}
Degenerative diseases are chronic non-communicable diseases such as heart disease, hypertension, diabetes, obesity and others. One of the degenerative diseases is hypertension. Hypertension is referred to as the "Silent Killer" because it is a deadly disease, without any symptoms as a warning to sufferers. Concerns about the emergence of new problems in hypertension will cause emotional mental disorders which are often shown by anxiety disorders. One of the lifestyle modifications that can cope with hypertension is to recommend being more relaxed. One alternative for relaxation in patients with hypertension is laughter therapy. This study aims to determine the effect of laughter therapy on reducing anxiety levels in hypertension sufferers in the Work Area. Method research using Literature review related to the effect of laughter therapy on reducing anxiety level in Hypertension patient. The results of the normality of the data showed that the data were normally distributed in the intervention group and the data were not normally distributed in the control group. From the results of this study, it is hoped that laughter therapy can be given contribution to reduce anxiety levelsin hypertensive patients, so that blood pressure in hypertensive patients can be controlled.
\end{abstract}

Keywords: Anxiety levels, hypertension sufferers, laughter therapy

Copyright $@ 2021$ IIK STRADA Indonesia All right reserved.

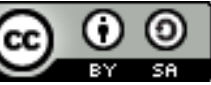

This is an open-acces article distributed under the terms of the Creative Commons AttributionShareAlike 4.0 International License.

\section{INTRODUCTION}

Non-communicable diseases or degenerative diseases since a few decades ago have become a separate problem segmentation for each country around the world. Together with the increasing complexity of the problems caused by various kinds of infectious diseases, cases of non-infectious diseases pose a double burden on the world of health. Until now, degenerative diseases have become the biggest cause of death in the world. In Indonesia, the epidemiological transition has caused a shift in disease patterns, in which chronic degenerative diseases have increased.

Degenerative diseases are chronic non-communicable diseases such as heart disease, hypertension, diabetes, obesity and others [3]. One of the degenerative diseases is hypertension. Hypertension is blood pressure persistent where the systolic pressure is above $140 \mathrm{mmHg}$ and the diastolic pressure is above $90 \mathrm{mmHg}$ [2]. Study aims to determine the effect of laughter therapy on reducing anxiety levels in hypertension sufferers in the Work Area. 


\section{METHOD}

Literature review related to the effect of laughter therapy on reducing anxiety level in Hypertension patient.

\section{RESULT AND DISCUSSION}

Hypertension is a public health problem that occurs in both developed and developing countries. It is feared that the high prevalence of hypertension can interfere with health development. The increase in the incidence of hypertension is inseparable from changes in people's behavior. If hypertension is not treated properly, it will cause complications of degenerative diseases such as kidney failure, heart failure, AMI, stroke and peripheral blood vessel disease. Therefore, it is necessary to know what factors can inhibit (protective) and increase (trigger) the incidence of hypertension, so that management and prevention of hypertension and its complications can be carried out [10].

Blood pressure varies in each individual, depending on age and daily activities. Blood pressure will tend to be high along with increasing age. State of mind also affects blood pressure reading. Stress, feelings of fear and anxiety, tend to trigger blood pressure increasing [10]. Hypertension is referred to as the "Silent Killer" because it is a deadly disease, without being accompanied by symptoms first as a warning to sufferers [10]. Concerns about the emergence of new problems in hypertension will cause emotional mental disorders which are often shown by anxiety disorders. The prevalence of mental emotional disorders in Indonesian population aged more than 15 years is $11.6 \%$, the general symptoms are anxiety disorders and depression associated with significant stress and impaired function over a certain period of time [4].

Salan (2000) states that in moderate anxiety, excessive adrenaline secretion occurs, causing blood pressure to increase, but in extreme fear a reaction can occur which is influenced by the parasympathetic component, causing blood pressure to increase [7]. Treatment of hypertension does not only rely on drugs from doctors or regulate diet alone, but it is also important to make our bodies always in a relaxed state. Relaxed condition needed to activate the parasympathetic nervous system which works against the sympathetic nerves, then the body will reduce the production of stress hormones [5].

One of Lifestyle modification that is able to overcome hypertension is to recommend being more relaxed. One alternative for relaxation in hypertension sufferers is laughter therapy. Laughter can help to control blood pressure by lowering stress hormones and creating a relaxed state to overcome anxiety [6].

Laughter therapy is very good, because it can improve the psychology of hypertension sufferers with anxiety and worries about complications. When people experience changes in psychological conditions such as stress, anxiety, depression, it can affect nerve cells to respond so as to stimulate hormone secretion. Laughter releases endorphins into the circulation so that the body becomes more comfortable and relaxed.

These endorphins are used as body morphines that cause a comfortable and healthy sensation [8]. When laughing, not only endorphins are released, but many positive hormones appear. The release of positive hormones, namely hormones that are released by the body when you feel happy, cheerful and happy, such as beta- endorphins and endomorphines.

This hormone will cause smooth blood circulation in the body so that the work functions of the organs run [8]. Laughter therapy aims to achieve joy in the heart that is released through the mouth in the form of laughter, or a smile that adorns the face, feelings of a free and happy heart, a spacious chest, smooth blood circulation so that it can prevent disease and maintain health [1].

Laughing 1 minute was equivalent to cycling for 15 minutes. This makes blood pressure decrease, there is an increase in oxygen in the blood which will speed up healing. Laughter also trains the chest, breathing, face, legs, and back muscles. In addition to physical, laughter also has an effect to mental health. Laughter has been shown to improve mood in a social context [9].

Laughter will relax tense muscles. Laughter also dilates blood vessels, thereby increasing blood flow throughout the body. So, laughing is a dynamic meditation or dynamic relaxation technique in a short time that can reduce a person's stress and anxiety [6]. 


\section{REFERENCES}

1. Andol. (2009). Laughter therapy. http://m.epochtimes.co.id

2. Bruner., \& Suddarth. (2002). Medical surgical nursing Ed.8. Jakarta: EGC.

3. Handajani, R., \& Maryani. (2009). Factors related to the pattern of death in degenerative diseases in Indonesia. Journal Health Systems Research, 13, 2010, 42-53.

4. Idaiani S., Suhardi \& Kristanto A. Y. (2009). Analysis of symptoms of mental emotional disorders of the Indonesian population. Indonesian Medical Magazine, 59-10.

5. Idrus., \& Faisal, M. (2010). Blood pressure patterns in generalized anxiety disorder.

6. Kataria., \& Madan. (2004). Laugh for no reason (laughing therapy). Jakarta: PT. grammar.

7. Salan. (2000). Some concepts about anxiety. Jakarta: Dharma Usada Foundation.

8. Setyoadi., \& Kushariyadi. (2011). Nursing modality therapy in psychogeriatric clients. Jakarta: Salemba Medika.

9. Suliswati, P., Tjie, A., Marahama, J., Sianturi, Y., \& Sumijatun. (2005). The basic concepts of mental health nursing. Jakarta: EGC.

10. Sustrani, L., Alam, S., Hadibroto., \& Iwan. (2004). Hypertension. Jakarta: PT. Main Library Gramedia. 